\title{
What comes First, the Spleen or the Valve? Management of Splenic Abscess complicating Infective Endocarditis: A Single-center Case Series
}

\author{
${ }^{1}$ Amelia M Pasley, ${ }^{2}$ Natasha Hansraj, ${ }^{3}$ Jason D Pasley, ${ }^{4}$ Jose J Diaz, ${ }^{5}$ Thomas M Scalea, ${ }^{6}$ Brandon Bruns
}

\begin{abstract}
Introduction: Splenic abscess is a rare and highly morbid extracardiac manifestation of infective endocarditis (IE) and has only been described in small case series in the literature. Emergency surgeons are often consulted for splenectomy; however, the optimal timing (before or after valve) of this intervention remains unclear. We hypothesized that definitive valve intervention, prior to splenectomy, would lead to superior patient outcomes.

Study design: A retrospective review of patients with IE and splenic abscess from June 2011 to June 2016 was performed at a quaternary referral center in the United States. Demographics, comorbid conditions, echocardiography results, intensive care unit (ICU)/hospital length of stay, operative interventions, splenectomy and valve replacement, and complications were collected. Patients were divided based on operation performed first: spleen first (SF) or valve first (VF). The primary outcome was mortality, with secondary outcomes including in-hospital morbidity.
\end{abstract}

Results: Ten patients met criteria for inclusion (8 SF, 2 VF). Median age was 45 years. About $90 \%$ were male, $60 \%$ were active intravenous drug abusers, and $100 \%$ had bacteremia (most commonly Enterococcus), with $50 \%$ of the patients having single-valve disease and $50 \%$ of the patients multivalvular disease. Total $90 \%$ had preserved cardiac function [ejection fraction $(E F)>40 \%$. All patients had splenic abscess diagnosed on HD 1, with $40 \%$ undergoing preoperative angioembolization. There was no difference in mortality between the groups (SF 25\% vs VF 0\%). There was no difference in the splenectomy portion of the operation, regardless of preoperative angioembolization.

Conclusions: Representing the largest modern case series on the topic, a $25 \%$ overall 6 -month mortality rate was observed; however, there was no difference in the order of operation noted in our population. Splenic abscess in conjunction with IE is a highly mortal combination; therefore, a large-scale multi-institutional approach should be utilized to delineate this population and address the order of operation as well as the role of splenic angioembolization in this subset of patients.

Keywords: Infective endocarditis, Splenic abscess, Surgical timing.

\footnotetext{
${ }^{1}$ Fellow, ${ }^{2}$ Resident, ${ }^{3,6}$ Attending Surgeon, ${ }^{4,5}$ Professor

${ }^{1-6}$ Department of Surgery, R Adams Cowley Shock Trauma Center, University of Maryland School of Medicine, Baltimore Maryland, USA

Corresponding Author: Amelia M Pasley, DO 348 Hauser Blvd. 227, Los Angeles, California, USA, Phone: +2488952250 e-mail: amelia.fiore@gmail.com
}

How to cite this article: Pasley AM, Hansraj N, Pasley JD, Diaz JJ, Scalea TM, Bruns B. What comes First, the Spleen or the Valve? Management of Splenic Abscess complicating Infective Endocarditis: A Single-center Case Series. Panam J Trauma Crit Care Emerg Surg 2018;7(1):77-81.

Source of support: Nil

Conflict of interest: None

\section{RESUMEN}

Introducción: El absceso esplénico es un extracardiaco raro y altamente mórbido manifestación de endocarditis infecciosa (IE) y solo tiene ha sido descrito en pequeñas series de casos en la literatura. Emergencia los cirujanos a menudo son consultados por esplenectomía; sin embargo, el tiempo óptimo (antes o después de la válvula) de esta intervención permanece poco claro. Presumimos que la intervención de válvula definitiva, antes de la esplenectomía, conduciría a mejores resultados en los pacientes.

Diseño del estudio: una revisión retrospectiva de pacientes con IE y absceso esplénico de junio de 2011 a junio de 2016 en un centro de referencia cuaternario en los Estados Unidos. Demografía, condiciones comórbidas, ecocardiografía resultados, unidad de cuidados intensivos (UCI) / hospitalización, estadía operativa intervenciones, esplenectomía y reemplazo de válvula, y complicaciones fueron recolectadas Los pacientes fueron divididos en base a operación realizada primero: bazo primero (SF) o válvula primero (VF). El resultado primario fue la mortalidad, con resultados secundarios incluida la morbilidad hospitalaria.

Resultados: Diez pacientes cumplieron los criterios de inclusión (8 SF, 2 FV). La mediana de edad fue de 45 años. Alrededor del $90 \%$ eran hombres, el $60 \%$ eran abusadores activos de drogas intravenosas, y el 100\% tenía bacteriemia (más comúnmente Enterococcus), con el $50 \%$ de los pacientes teniendo enfermedad de una sola válvula y el $50 \%$ de los pacientes multivalvulares enfermedad. El $90 \%$ total conservaba la función cardíaca [eyección fracción (EF)> 40\%]. Todos los pacientes tenían un absceso esplénico diagnosticado en HD 1, con un $40 \%$ de angioembolización preoperatoria. No hubo diferencia en la mortalidad entre los grupos (SF $25 \%$ vs VF $0 \%$ ). No hubo diferencia en la porción de esplenectomía de la operación, independientemente de la angioembolización preoperatoria.

Conclusiones: Representando la mayor serie de casos modernos en el tema, se observó una tasa de mortalidad general de 6 meses del 25\%; sin embargo, no hubo diferencia en el orden de operación observado en nuestra población. Absceso esplénico en conjunción con IE es una combinación altamente mortal; por lo tanto, una gran escala enfoque multi-institucional

Presented in the general competetion, annual Congress of Panamerican Trauma Society, Maceio, Brazil, November 2017 
debería ser utilizado para delinear esto población y abordar el orden de la operación, así como la papel de la angioembolización esplénica en este subgrupo de pacientes.

Palabras clave: Absceso esplénico, Endocarditis infecciosa, Quirúrgico sincronización

\section{INTRODUCTION}

Diagnostic and therapeutic methods have drastically improved over time, and IE is a highly lethal cardiac condition with $20 \%$ of the patients dying within the first 12 months of diagnosis. ${ }^{1,2}$ Heterogeneity of the overall disease burden causes subsets of this population with need for additional treatment modalities, especially with extracardiac manifestations. A significant extracardiac manifestation of IE is splenic abscess.

Early cardiac surgical management for complicated IE is indicated, depending on valve dysfunction resulting in significant heart failure, resistant organisms (Streptococcus aureus, fungi), heart block, abscess, prolapsed prosthetic valve endocarditis, large mobile vegetations, and recurrent emboli. ${ }^{3}$

Although multiple case reports and series have been published, no definitive consensus has been obtained on order of operation of splenectomy or infected valve replacement. Proponents of SF argue that by this method there is a decrease in the risk of seeding new valve with bacteremia from ongoing splenic abscess. Other studies recommend replacing the VF so the patient does not have worsening heart failure following splenectomy. Others recommend simultaneous or one-stage splenectomy and valve replacement if the patient has an unstable cardiac status or congestive heart. ${ }^{4-9}$

Knowing that early cardiac surgery for IE portends the best outcomes, we hypothesized that definitive valvular intervention, prior to splenectomy, would lead to superior outcomes.

\section{METHODS OF RESEARCH}

After institutional review board approval was obtained, a retrospective review was performed for patients requiring splenectomy in conjunction with IE from June 1, 2010, to June 1, 2016, at the University of Maryland Medical Center, a large tertiary referral center for the state. Those undergoing valve or splenectomy alone or nonoperative management were excluded from the study. The cohort was divided into the SF or VF groups.

Patient demographics and comorbidities were collected. Preoperative variables collected included type of bacteremia, valve involved, $\mathrm{EF}$, and method of diagnosis of valvular disease. Presence of other concurrent infarcts was also documented.
Six-month mortality rates were compared between the SF and VF group. Post-operative complications were compared after splenectomy to include left upper quadrant abscess, persistent bacteremia, pancreatic tail leak, worsening cardiac failure, unexpected return to the operating room within 24 hours, and acute renal failure. Postoperative complications were compared after valve replacement to include new abscess, persistent bacteremia, cerebral vascular accident, deep vein thrombosis/ pulmonary embolism, unexpected return to the operating room within 24 hours, acute renal failure, pleural effusion, and sternal infection.

In addition, in the splenectomy group, comparison of blood loss, transfusion, and fluid requirements and ease of procedure were compared in groups with or without preoperative splenic embolization (SE).

Continuous variables are presented as mean with standard deviation. Categorical variables are presented as mean and percentage or median and interquartile range. Nonparametric test for trend was used to test for trends in proportion for mortality and complication rates. Due to our small sample size, statistical significance was not obtained.

\section{RESULTS}

During the 6-year time frame, 14 patients presented with splenic abscess and IE. Four patients were excluded for either non-operative management or only valve surgery. Ten patients with IE undergoing valve surgery and splenectomy were included in the cohort. Two patients $(20 \%)$ underwent valve repair first (VF), whereas eight patients $(80 \%)$ underwent SF. Median age was higher in the SF group (53.5 years) compared with the VF group (30 years). A higher prevalence of comorbidities was noted in the SF group as compared with the VF group. Overall, $60 \%$ of the patients were active intravenous drug users, with 100\% in VF cohort compared with $25 \%$ in SF cohort (Table 1).

All of the patients had bacteremia on presentation. In the VF group, pathology was present equally in the aortic valve and mitral valve, whereas in the SF group, three patients had single-valve pathology, three patients had two-valve pathology, and two patients had three-valve pathology. About $90 \%$ of the patients had preserved cardiac function, $\mathrm{EF}>40 \%$.

Distal infarcts were common in both groups. Renal infarcts were seen $37.5 \%$ of the time in SF group, while cerebral infarcts were noted in all of the VF group (Table 2).

Mortality was higher in the SF group (25 vs $0 \%$; Table 3). Postoperative complications including postoperative abscess, persistent bacteremia, renal failure, as well as length of stay, ICU days, and vent days were similar between the two groups (Tables 4 and 5). 
What comes First, the Spleen or the Valve?

\begin{tabular}{|c|c|c|c|}
\hline \multicolumn{4}{|c|}{ Table 1: Demographics } \\
\hline Characteristics & $\begin{array}{l}\text { Mean (SD) or } \\
\text { median (IQR) or } \\
n(\%), n=10\end{array}$ & $\begin{array}{l}\text { Valve, } \\
n=2(\%)\end{array}$ & $\begin{array}{l}\text { Spleen, } \\
n=8(\%)\end{array}$ \\
\hline Age & $45(29-58)$ & 30 & 53.5 \\
\hline Male & $9(90)$ & 2 & 7 \\
\hline BMI & $25(22-34)$ & 25.1 & 28.9 \\
\hline \multicolumn{4}{|l|}{ Comorbidities } \\
\hline HTN & $4(40)$ & $0(0)$ & $4(50)$ \\
\hline $\mathrm{DM}$ & $4(40)$ & $0(0)$ & $4(50)$ \\
\hline $\mathrm{CHF}$ & $0(0)$ & $0(0)$ & $0(0)$ \\
\hline COPD & $2(20)$ & $0(0)$ & $2(25)$ \\
\hline ESRD & $2(20)$ & $0(0)$ & $2(25)$ \\
\hline \multicolumn{4}{|l|}{$\begin{array}{l}\text { Intravenous drug } \\
\text { abuse }\end{array}$} \\
\hline Current & $4(40)$ & $2(100)$ & $2(25)$ \\
\hline Remote or unknown & $6(60)$ & $0(0)$ & $6(75)$ \\
\hline \multicolumn{4}{|c|}{$\begin{array}{l}\text { SD: Standard deviation; IQR: Interquartile range; BMI: Body } \\
\text { mass index; HTN: Hypertension; DM: Diabetes mellitus; CHF: } \\
\text { Congestive heart failure; COPD: Chronic obstructive pulmonary } \\
\text { disease; ESRD: End-stage renal disease }\end{array}$} \\
\hline \multicolumn{4}{|c|}{ Table 3: Mortality and hospitalization } \\
\hline Characteristics & $V F, n=2$ & & $n=8$ \\
\hline 6 months mortality & $0(0 \%)$ & & $(25 \%)$ \\
\hline Vent days & $7.5(3.75-11.25)$ & & $5(1-20.5)$ \\
\hline ICU LOS (days) & $22(16-28)$ & & $5.5(4-31.5)$ \\
\hline LOS (days) & $49.5(37.5-61.25$ & & $(27-69.5)$ \\
\hline
\end{tabular}

Table 4: Splenectomy complications: postoperative complications after splenectomy

\begin{tabular}{lll}
\hline Complications & $V F, n=2(\%)$ & $S F, n=8(\%)$ \\
\hline LUQ abscess & $1(50)$ & $1(12.5)$ \\
Persistent bacteremia & $0(0)$ & $0(0)$ \\
Pancreatic tail leak & $0(0)$ & $0(0)$ \\
Worsened heart failure & $1(50)$ & $0(0)$ \\
Take back to OR < 24 hrs & $0(0)$ & $0(0)$ \\
Acute renal failure & $0(0)$ & $4(50)$ \\
\hline
\end{tabular}

LUQ: Left upper quadrant

Overall, $40 \%$ of the patients underwent SE prior to splenectomy, $100 \%$ had SE in the VF group, and $25 \%$ had $\mathrm{SE}$ in the SF group. Surgeon preference seemed to decide on who was embolized prior to splenectomy. It was noted that SE patients had 1.6 times higher estimated blood loss, 1.2 times higher transfusion needs, however had 3 times greater ease of spleen removal per surgeon description, and 0.65 times fluid is needed as compared with those who did not receive pre-operative embolization. The two groups were noted to have similar operative time and spleen size, despite embolization (Table 6). Overall, SE did not change the operative time and had a higher EBL compared with those not embolized.

Table 2: Specific findings

\begin{tabular}{llll}
\hline Characteristics & $n=10(\%)$ & $V F, n=2(\%)$ & $S F, n=8(\%)$ \\
\hline Bacteremia & $10(100)$ & $2(100)$ & $8(100)$ \\
MRSA & $1(10)$ & $1(50)$ & \\
MSSA & $1(10)$ & & $1(12.5)$ \\
Streptococcus & $1(10)$ & & $1(12.5)$ \\
Enterococcus & $2(20)$ & & $2(25)$ \\
Others & $5(50)$ & $1(50)$ & $4(50)$ \\
Valve involved & & & \\
MV only & $3(30)$ & $1(50)$ & $2(25)$ \\
AV only & $2(20)$ & $1(50)$ & $1(12.5)$ \\
TV only & $0(0)$ & $0(0)$ & $0(0)$ \\
MV and TV & $1(10)$ & & $1(12.5)$ \\
MV and AV & $2(20)$ & & $2(25)$ \\
MV, TV, and AV & $2(20)$ & & $2(25)$ \\
Diagnosis & & & $3(37.5)$ \\
TTE & $4(40)$ & & $0(0)$ \\
TEE & $0(0)$ & & $5(62.5)$ \\
Combination & $6(60)$ & $2(100)$ & $6(75)$ \\
Large vegetation & $7(70)$ & $1(50)$ & $1(12.5)$ \\
EF & & & $7(87.5)$ \\
30-40\% & $1(10)$ & & $3(37.5)$ \\
>40\% & $9(90)$ & $2(100)$ & \\
Additional infarcts & & & \\
Renal infarcts & $3(30)$ & 0 & \\
Cerebral infarcts & $5(50)$ & $2(100)$ & \\
\hline
\end{tabular}

MRSA: Methicillin-resistant Staphylococcus aureus; MSSA: Methicillin-sensitive Staphylococcus aureus; MV: Mitral valve; AV: Aortic valve; TV: Tricuspid valve; TTE: Transthoracic echocardiogram; TEE: Transesophageal echocardiogram

Table 5: Valvular complications: postoperative complications after valve replacement

\begin{tabular}{lll}
\hline Complications & $V F, n=2(\%)$ & $S F, n=8(\%)$ \\
\hline New abscess & $0(0)$ & $1(12.5)$ \\
Persistent bacteremia & $0(0)$ & $0(0)$ \\
Cerebral vascular accident & $0(0)$ & $0(0)$ \\
DVT/PE & $0(0)$ & $1(12.5)$ \\
Take back to OR $<24$ hrs & $0(0)$ & $2(25)$ \\
Acute renal failure & $2(100)$ & $1(12.5)$ \\
Pleural effusion & $1(50)$ & $1(12.5)$ \\
Sternal infection & $0(0)$ & $1(12.5)$
\end{tabular}

DVT/PE: Deep vein thrombosis and pulmonary embolism

Table 6: Splenectomy considerations with and without embolization

\begin{tabular}{lll}
\hline & $\begin{array}{l}\text { Splenic } \\
\text { embolization, } \\
n=4\end{array}$ & $\begin{array}{l}\text { No } \\
\text { embolization, } \\
n=6\end{array}$ \\
\hline EBL $(\mathrm{mL})$ & 831 & 533 \\
Fluids $(\mathrm{mL})$ & 2000 & 3066 \\
PRBC transfusion (units) & 3 & 2.5 \\
Operative time $(\mathrm{hr})$ & 2 & 2.25 \\
Spleen size on CT $(\mathrm{cm})$ & 13.6 & 14.38 \\
Pathological spleen size $(\mathrm{cm})$ & 17.88 & 17.85 \\
Ease of removal & $3(75 \%)$ & $2(33 \%)$ \\
\hline
\end{tabular}

CT: Computed tomography: EBL: Estimated blood loss: PRBC: Packed red blood cells 


\section{DISCUSSION}

Infective endocarditis causes significant cardiac and extracardiac manifestations, and despite optimal care, still has a significant mortality. Indications for surgery are consistent for both valvular repair and splenectomy. When concurrent infections are present, timing of operations remains in question.

Several authors believe that splenectomy should be performed first to remove the extracardiac source of infection to prevent secondary infection of the new valves. ${ }^{8,9}$ In our study, we did not note any secondary infection of the new valve in the VF group.

In this small study, $90 \%$ of patients had preserved EF; therefore, this may have had a significant bias and impact on which operation was performed first and on our survival. Mortality was higher in the SF group of $25 \%$ compared with $0 \%$ in the VF group; however, due to our limited sample size, statistical significance could not be obtained. Furthermore, no significant difference was noted in complications, hospital or ICU length of stay.

Splenectomy in patients with splenomegaly is noted to have a higher rate of iatrogenic injuries, capsular tears, and venous bleeding, making it more challenging operatively. With pure splenic pathology, Poulin described a decrease in operative time and estimated blood loss when $\mathrm{SE}$ was performed prior to laparoscopic splenectomy. ${ }^{10}$ Similarly, Naoum et al ${ }^{11}$ demonstrated 10 times decrease in blood loss with preoperative embolization. However, in our study, preoperative SE did not lead to decreased operative time and blood loss. We noted a higher blood loss and transfusion requirement although there was a reported increased surgical ease of operation. This discrepancy may be confounded by a smaller number of patients and multiple surgeons with different experience in performing operations.

Similar to other papers, our study demonstrates no difference in mortality. With our small population, we cannot deduce definitive evidence to recommend one procedure over the other in all patients. Theoretically, if the patient has intractable heart failure, we would recommend initial urgent valve replacement, with concurrent or subsequent splenectomy; however, a larger retrospective cohort or multicenter trial is needed to definitively answer the question of SF vs VF.

\section{CONCLUSION}

This is the largest modern case series on timing of splenectomy for abscess and valve replacement in IE. This cohort demonstrated a $25 \%$ overall mortality with no detectable difference between SF and VF groups. A large-scale multi-institutional approach is needed to help answer the question of SF vs VF.

\section{REFERENCES}

1. Cabell CH, Jollis JG, Peterson GE, Corey GR, Anderson DJ, Sexton DJ, Woods CW, Reller LB, Ryan T, Fowler VG Jr. Changing patient characteristics and the effect on mortality in endocarditis. Arch Intern Med 2002 Jan;162(1):90-94.

2. Thuny F, Di Salvo G, Belliard O, Avierinos JF, Pergola V, Rosenberg V, Casalta JP, Gouvernet J, Derumeaux G, Iarussi $\mathrm{D}$, et al. Risk of embolism and death in infective endocarditis: prognostic value of echocardiography: a prospective multicenter study. Circulation 2005 Jul;112(1):69-75.

3. Thuny F, Grisoli D, Collart F, Habib G, Raoult D. Management of infective endocarditis: challenges and perspectives. Lancet 2012 Mar;379(9819):965-975.

4. Gegouskov V, Petrov P, Simov D, Danov V, Blagov J, Petrov S. One-stage mitral valve replacement and splenectomy in splenic infarcts and infective endocarditis. Internet J Thorac Cardiovas Surg 2009;14(2).

5. Kang DH. Timing of surgery in infective endocarditis. Heart 2015 Aug;101:1786-1791.

6. Delahaye F, Cerlard M, Roth O, de Gevigney G. Indications and optimal timing for surgery in infective endocarditis. Heart 2004 Jun;90(6):618-620.

7. Blasi S, De Martino A, Levantino M, Pratali S, Anastasio G, Bortolotti U. Splenectomy and valve replacement in patients with infective endocarditis and splenic abscesses. Ann Thorac Surg 2016 Sep;102(3):e253-e255.

8. Elasfar A, AlBaradai A, AlHarfi Z, Alassal M, Ghoneim A, AlGhofaili F. Splenic abscess associated with infective endocarditis: case series. J Saudi Heart Assoc 2015 Jul;27(3): 210-215.

9. Simsir SA, Cheeseman SH, Lancey RA, Vander Salm TJ, Gammie JS. Staged laparoscopic splenectomy and valve replacement in splenic abscess and infective endocarditis. Ann Thorac Surg 2003 May;75(5):1635-1637.

10. Wu Z, Zhou J, Pankaj P, Peng B. Comparative treatment and literature review for laparoscopic splenectomy alone versus preoperative splenic artery embolization splenectomy. Surg Endosc 2012 Oct;26(10):2758-2766.

11. Naoum JJ, Siberfein EJ, Zhou W, Sweeney JF, Albo D, Brunicardi FC, Kougias P, El Sayed HF, Lin PH. Concomitant intraoperative splenic artery embolization and laparoscopic splenectomy versus laparoscopic splenectomy: comparison of treatment outcome. Am J Surg 2007 Jun;193(6):713-718. 


\section{INVITED COMMENTARY}

\section{What comes First, the Spleen or the Valve? Management of Splenic Abscess complicating Infective Endocarditis: A Single-center Case Series}

Infective endocarditis is the most common condition predisposing a patient to splenic abscess or infarction due to septic emboli. This is a well-described but rare complication of infective endocarditis. Rapid diagnosis and treatment are essential as its course can prove fatal. The treatment of choice has been antibiotics, splenectomy, and valve replacement surgery. Splenic tissue is very fragile and a splenic rupture can result from minimal trauma. The general recommendation is to perform splenectomy prior to valve replacement to prevent potential splenic rupture and/or re-infection of the valve prosthesis. The group from R Adams Cowley Shock Trauma has eloquently presented their data on this topic in which they questioned the sequence in which the surgical procedures should be performed. A total of 14 patients presented with splenic abscess and infective endocarditis during the study period at their institution, four patients were excluded for either non-operative management or only valve surgery. Although correctly excluded from the study, these four patients are of enormous clinical importance as a comparative control group as the current trend is towards non-operative or minimally invasive management. A combined one-stage procedure is also an option which was not included or not performed at the institution.

The authors have recognized the limitations of their study which include small sample size, non-randomization and it being retrospective but fall short in controlling for the inherent surgeon bias in group selection and for those that received pre-operative splenic embolization (SE). They noted that SE did not change the operative time and had 1.2 time's higher transfusion needs and 1.6 times higher estimated blood loss compared with those not embolized. These findings put into question the indications and effectiveness of pre-operative embolization in these cases.

The authors also conclude that "Theoretically, if the patient has intractable heart failure, we would recommend initial urgent valve replacement, with concurrent or subsequent splenectomy" which I agree with completely but of the ten patients included in the study only 1 patient had an ejection fraction of $30-40 \%$ and that patient had a splenectomy first.

I applaud the authors for their review of their experience and their efforts in answering an important clinical question that continues to elude us.

Michael W Parra

Trauma Research Director Clinical Assistant Professor

Florida International University School of Medicine Florida Atlantic University School of Medicine Broward General Level I Trauma Center Fort Lauderdale, Florida 